ISSN 1392-3196 / e-ISSN 2335-8947

Zemdirbyste-Agriculture, vol. 108, No. 3 (2021), p. 271-278

DOI 10.13080/z-a.2021.108.035

\title{
The effect of genotype and temperature interaction on pollen performance in the pistils of autochthonous sour cherry cultivar 'Feketićka'
}

\author{
Sanja RADIČEVIĆ ${ }^{1}$, Vladislav OGNJANOV ${ }^{2}$, Slađana MARIĆ ${ }^{1}$, Goran BARAĆ ${ }^{2}$ \\ ${ }^{1}$ Fruit Research Institute \\ Kralja Petra I 9, 32000 Čačak, Republic of Serbia \\ E-mail: sradicevic@institut-cacak.org \\ ${ }^{2}$ University of Novi Sad, Faculty of Agriculture \\ Trg Dositeja Obradovića 8, 21101 Novi Sad, Republic of Serbia
}

\begin{abstract}
The study of pollen performance in vivo in the pistils of autochthonous sour cherry (Prunus cerasus L.) cultivar 'Feketićka' under different pollination modes was conducted. The experiment included self- and cross-pollination with sour cherry cultivars 'Cigančica', 'Čačanski Rubin', 'Érdi Bötermö' and 'Majurka', sweet cherry cultivars 'Early Star' and 'Newstar' as well as open pollination variant. The results were considered in the context of agroecological conditions of Vojvodina Province of the Republic of Serbia, which is typical of 'Feketićka' sour cherry growing. The impact of variability factors on pollen tube growth efficiency manifested as an overlapping effect of polliniser genotype, its requirement for flowering temperatures, the influence of female genotype on pollen performance and the response of male-female relations to air temperature. With less than $6 \%$ of fruit set after selfing, 'Feketićka' can be classified as a partially self-compatible. Among the investigated pollinisers for 'Feketićka', the best performance was shown by 'Cigančica', whereas 'Čačanski Rubin' and 'Érdi Bötermö' showed the lowest parameters of pollen tubes growth in vivo, so they are not recommended as pollinisers. Considering the air temperature during the flowering, 'Feketićka' displayed the opposite behaviour, preferring higher/lower temperatures as polliniser/pollinated cultivar, respectively.
\end{abstract}

Key words: autochthonous cultivar, temperature at flowering, fruit set, ovule vitality, pollen tube growth, Prunus cerasus.

\section{Introduction}

Sour cherry (Prunus cerasus L.) is an allotetraploid fruit species, which originated from natural hybridization between ground cherry (Prunus fruticosa Pall.) and unreduced pollen of sweet cherry (Prunus avium L.), widely spread in the temperate continental zone. Due to its polyploid nature and continued interspecies gene flow, sour cherry is a polymorphic species with many variations in its morphological properties, particularly in the centre of diversity in Eastern Europe. The variability in sour cherry germplasm is an abundant source of diversity for growing the genotypes as final products of natural selection or as parents in planned hybridization. In this respect, the best results have been achieved in Hungary, where a number of sour cherry cultivars with good pomological properties and resistance to causal agents of diseases were obtained by landrace selection and cross-breeding based on the autochthonous cultivars (Szügyi et al., 2016). Such programmes have also been in progress in many European countries. Central and Eastern Europe were identified as target locations for germplasm collection in the first step of the long-term sour cherry breeding strategy of the USA (Iezzoni et al., 2017).
In addition to sour cherry 'Oblačinska' widespread throughout the territory of the Republic of Serbia, in northern parts (the southern edge of the Pannonian Basin), the local cultivar 'Majurka' is sporadically distributed along with various clones of 'Köröser Weichsel' and 'Cigančica' ('Cigány Meggy'). In the limited area of Feketić, sour cherry orchards and individual trees of high-quality fruits with early ripening and pronounced resistance to causal agents of diseases have also been grown. They were probably brought by soldiers from Austro-Hungary and locally named as 'Feketićka' ('Majusi Fekete Meggy').

Genetic variability within sour cherry cultivar 'Feketićka' is a result of numerous chance seedlings mixed with suckers, traditionally used in propagation. The fruits are characterised as morello type: large in size, dark purple-red skin, medium firmness, long stem and excellent food quality, pleasant aromatic flavour, described as intense (Ognjanov et al., 2016), and can be eaten fresh as well as processed into canned, frozen, candied and dried forms, juice, jams, jellies, wine, liqueur and brandy. The ripening time is on the second week of

Please use the following format when citing the article:

Radičević S., Ognjanov V., Marić S., Barać G. 2021. The effect of genotype and temperature interaction on pollen performance in the pistils of autochthonous sour cherry cultivar 'Feketićka'. Zemdirbyste-Agriculture, 108 (3): 271-278. DOI 10.13080/z-a.2021.108.035 
June in Northern Serbia conditions, about two weeks before 'Heimanns Konserven Weichsel' (Radičević et al., 2012), i.e., five days before 'Érdi Bötermö' (Ognjanov et al., 2016). Selected clones are tolerant of Monilia laxa (Ehrenb.) Sacc. \& Voglino and Blumeriella jaapii (Rehm.) v. Arx. (Radičević et al., 2012), which make them interesting for organic production and use in breeding as a potential donor for polygenic resistance.

Fertility in sour cherry is controlled by a gametophytic self-incompatibility (GSI) system similar to other Rosaceae, whereas the genetics of self(in)compatibility is more complex than for sweet cherry. Several studies revealed the genotype-dependent loss of self-incompatibility, meaning that genetic changes and not polyploidy itself cause self-compatibility (Tsukamoto et al., 2010). Sour cherry produces diploid pollen; therefore, if a pollen grain contains at least one functional S-haplotype that matches a functional S-haplotype in the style, the pollen will be self-incompatible. If stylar inhibition of pollen tube growth occurs, pollen tubes grow normally and then their growth stops at about half-way down the style. As from aspect of fruit set, sour cherries behaved as self-incompatible, partially self-compatible and selfcompatible (Schuster et al., 2017). Thus, to optimize cultivation technology and realising yielding potential, it is necessary to identify suitable pollinisers for selfincompatible and partially self-compatible genotypes.

Fruit set and yield of sour cherry are also under a strong influence of other factors of the reproductive process: overlap of the main cultivar and polliniser during the flowering, pollen quality and assurance of its transfer, stigma receptivity, ovule longevity, regularity of postfertilisation biology processes, etc. Significant factors for the regularity of the fertilisation process are primary ovule and embryo sac development at the moment of flower opening as well as their vitality during the full-flowering stage. The occurrence of callose in the chalazal part of the ovules and its spread through the integument until the entire ovule is affected could be identified by aniline-blue staining and observation under UV light, and is the first visible symptom of ovules degeneration in Prunus species cherries (Stösser, Anvari, 1982), almond (Pimienta, Polito, 1982) and peach (Arbeloa, Herrero, 1985).

Among environmental conditions, air temperature is the most important factor, which influences both pollen tube growth and ovule longevity in cherries (Hedhly, 2011; Radičević et al., 2016; 2018). The changes in environmental conditions include warmer winters and higher risks of frosts in the early spring and may lead to a wide range of problems related to flowering stage and fruit set (Wenden, Mariadassou, 2017).

The experiment was aimed to determine reproductive behaviour of autochthonous sour cherry 'Feketićka' as pollinated cultivar and self-polliniser, the level of self-(in)compatibility as well as the best crosspolliniser, to optimize the orchard management for this economically important sour cherry cultivar and its proper utilization in sour cherry breeding.

\section{Materials and methods}

Plant material and experimental design. The experiment was carried out during two consecutive years $(2016-2017)$ in the orchard located in Feketic $\left(45^{\circ} 39^{\prime} 12.4^{\prime \prime} \mathrm{N}, 19^{\circ} 41^{\prime} 54.8^{\prime \prime} \mathrm{E}, 94 \mathrm{~m}\right.$ a.s.1.), Mali Iđoš municipality, Serbia. The area is characterized by a moderately continental climate: average annual temperature $10.80^{\circ} \mathrm{C}$, temperature during the vegetation period $16.8^{\circ} \mathrm{C}$, precipitation rate $588 \mathrm{~mm}$.

The flowers of cultivar 'Feketićka' were pollinated with pollen of sour cherry (Prunus cerasus L.) cultivars 'Cigančica', 'Ćačanski Rubin', 'Érdi Bötermö' and 'Majurka' and sweet cherry (Prunus avium L.) cultivars 'Early Star' and 'Newstar'. Pollinisers were chosen taking into account an adequate flowering beginning (at the same time or one/two days before
'Feketićka') and multi-year overlapping with the full flowering of 'Feketićka'. Pollen of 'Feketićka' was also used in self-pollination (SP) mode.

The orchard was founded in the spring of 2007; the above-mentioned cultivars were grafted on mahaleb (Prunus mahaleb L.) seedlings. Narrow-pyramidal crown, a spacing of $4.0 \times 1.5 \mathrm{~m}$ and standard cultural practices were used. A randomized block design was applied, including three replications with three trees each (a total of nine trees).

The air temperature monitoring. The air temperature was continuously measured before and during the full flowering stage. The average mean, maximum and minimum daily temperatures of full flowering stage were calculated (as the date of full flowering, the day when $80 \%$ of flowers were open was considered; ten days thereafter were also included) as well as the same temperatures before full flowering of 'Feketićka' (eight days).

Pollen germination in vitro. A total of 50 flowers in the stage of the late balloon (growth stage 60, according to $\mathrm{BBCH}$ scale) (Meier, 2018) were taken from all sides of trees per each cultivar. The anthers were collected in paper boxes and stored in the laboratory for 24-48 hours at $20^{\circ} \mathrm{C}$ temperature until they released pollen grains. Pollen was plated in three Petri dishes on a nutrient medium $(1 \%$ agar, $12 \%$ sucrose) and incubated at $20^{\circ} \mathrm{C}$ temperature for 24 hours. The germinated pollen grains were counted in three fields of view, each including about 100 pollen grains, by the microscope Olympus BX61 (Japan), light regime. When the pollen tubes exceeded the radius of grains, the grains were considered as germinated. Pollen germination in vitro value was calculated as the average for the total of nine fields of view.

Pollination experiment in the field. At total of 10.500 flowers of 'Feketićka' trees were selected (twoyear-old branches with approximately 80-100 flowers at late balloon stage, 1.500 for each polliniser), emasculated and protected with paper bags. The branches at the same stage were also selected for the open pollination mode -1.500 flowers without emasculation and bagging. The anthers of pollinisers were collected and allowed to burst for 24-48 hours at $20^{\circ} \mathrm{C}$ temperature. Hand-pollination was done at the beginning of full flowering $(\mathrm{BBCH}$ 65) (Meier, 2018). A total of eight combinations were processed. The pollinated branches were isolated again, and bags were removed three weeks after pollination.

Pollen performance in vivo and ovule fluorescence observation. A total of 30 pistils per treatment were sampled and fixed in FPA (70\% ethanol (v:v), propionic acid and formaldehyde, in a ratio 90:5:5) at three terms: 72,144 and 240 hours after pollination. The pistils were processed by aniline blue staining (Preil, 1970; Kho, Baër, 1971). The styles were separated from the ovaries, opened along the suture and squashed using a cover husk. The ovaries were dissected along the suture, and primary ovule integuments were cut longitudinallytangentially to enable observation of pollen tube penetration through micropyle and nucellus. The pistils were observed under UV light by microscope Olympus BX61 (Japan) and analysed by software AnalySIS using multiple image analysis (MIA). Pollen tubes were counted in the upper third and the base of the style (magnification of $200 \times)$ and in the ovary $(100 \times)$; their numbers were presented as an average of three fixation samples. The percentage of pistils with the longest pollen tubes penetrating to their particular parts was the parameter for consideration of pollen tube growth rate. Fertilisation percentage was defined as the total number of pistils with penetration into the nucellus 240 hours after pollination. The percentage of primary ovules without fluorescence signs was presented for each pollination mode and for two fixation terms ( $3^{\text {rd }}$ and $6^{\text {th }}$ day after pollination).

Fruit set was determined at the beginning of ripening. The percentage of fruits per total number of pollinated flowers remaining after the final fixation was calculated (the minimum number was 600 per combination). 
Statistical analysis. A two-factor analysis of variance (ANOVA) was used with arcsine square-root data transformations for the results expressed in percentages. Duncan's multiple range test was applied for testing the significant differences among mean values (at $P \leq 0.05$ ). Correlation-regression analysis and Pearson's correlation coefficients were used for determining correlations among the parameters. Two matrices were obtained: one including reproductive parameters for pollinisers (male reproductive behaviour), and the other for parameters of the pollinated cultivar (female reproductive behaviour) Statistical software package SPSS, version 8.0 (SPSS Inc., USA) was used.

\section{Results and discussion}

Air temperature conditions before and during the full flowering. The average mean daily temperatures for the day of full flowering and following ten days were $15.49^{\circ} \mathrm{C}$ and $11.83^{\circ} \mathrm{C}$ by years, respectively (Figure 1 ).
In 2016, during the full flowering, maximum temperatures were occasionally exceeding $25^{\circ} \mathrm{C}$ (five days; in seven days they were above $21^{\circ} \mathrm{C}$ ) (Figure 1A) In 2017, maximum temperature that exceeded $25^{\circ} \mathrm{C}$ was noticed only the first day with the maximum higher than $21^{\circ} \mathrm{C}$ in five days (Figure 1B). The minimum temperatures before full flowering in 2016 were below $5^{\circ} \mathrm{C}$ in two days and in 2017 in five days, reaching $0^{\circ} \mathrm{C}$ in two days. The average mean, maximum and minimum daily temperatures during full flowering in 2016 were higher by $3.66,2.73$ and $5.55^{\circ} \mathrm{C}$, respectively. Before full flowering, the temperature differences were even higher and amounted to $5.04,5.18$ and $4.98^{\circ} \mathrm{C}$, respectively.

Pollen germination in vitro. Sweet cherry cultivars had generally better pollen germination in vitro than sour cherries: the highest values were observed in sweet cherries 'Newstar' and 'Early Star', whereas it had the lowest value in sour cherry 'Cačanski Rubin' (Figure 2).

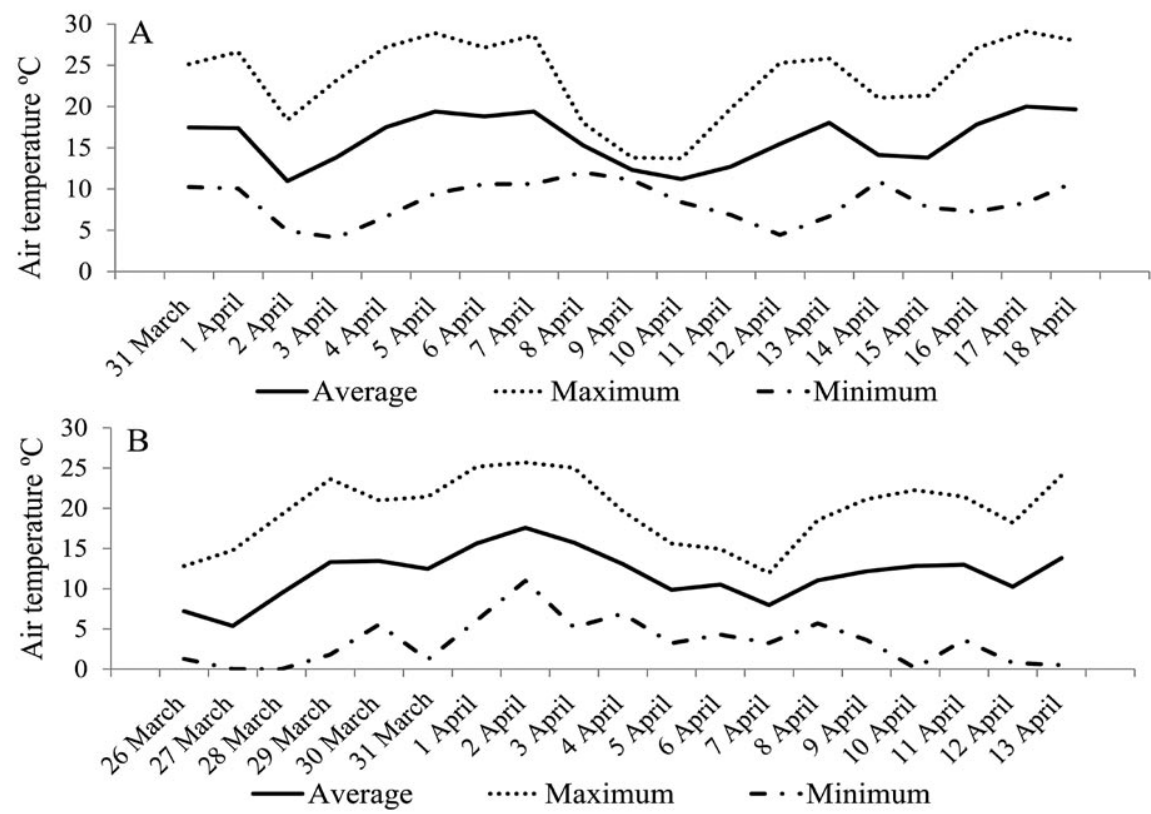

Figure 1. The air temperature before and during the full flowering stage of sour cherry cultivar 'Feketićka' in 2016 (A) and 2017 (B)

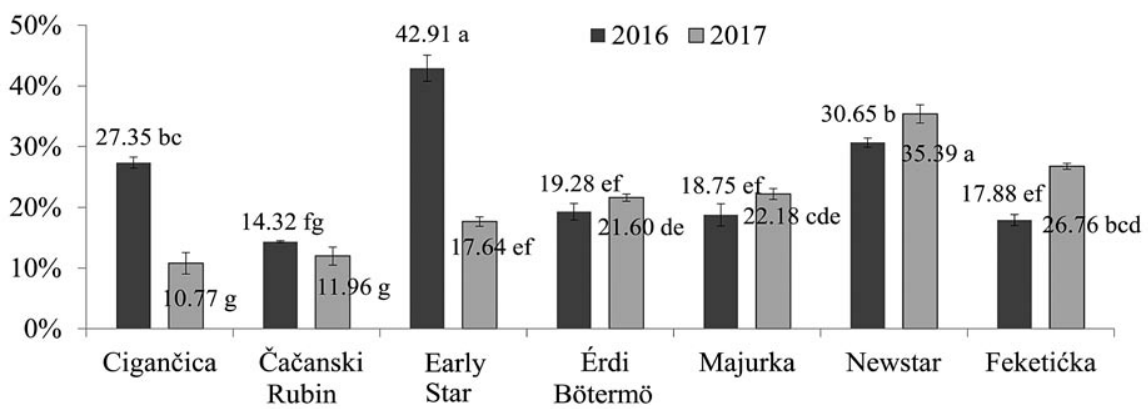

Note. The bars above the columns denote the standard errors; mean values followed by the different lower-case letters represent significant differences at $P \leq 0.05$.

Figure 2. Pollen germination in vitro of different pollinisers for sour cherry cultivar 'Feketićka'

In this experiment, pollen germination results obtained for sweet cherry cultivars are consistent with previous results, received with a medium supplemented with a similar sucrose content (Radičević et al., 2013; Pal et al., 2015). The opposite tendencies by years were observed: three of the pollinisers ('Cigančica', 'Cačanski Rubin' and 'Early Star') had higher values for pollen germination in vitro in the first year, whereas for the other cultivars higher values were observed in the second year of the experiment (Figure 2). The opposite tendencies manifested in pollen germination in vitro by years are directly associated with the regularity in microsporogenesis. In autochthonous sour cherry cultivar 'Oblačinska', pollen germination in vitro positively correlated with microsporogenesis regularity (Fotirić Akšić et al., 2016) and was strongly influenced by the genotype (Fotirić Akšić et al., 2017).

Efficiency of pollen tubes growth in vivo. A drastic reduction of the number of pollen tubes in lower sections of the pistils was observed in all 8 combinations 
(Table 1; Figure 3A-C and E). Sweet cherry cultivar 'Newstar' induced the highest number of pollen tubes, whereas the pollen tube number of sour cherry cultivars 'Érdi Bötermö' and 'Majurka' was the lowest.

The number of pollen tubes in style was generally lower in 2017 , i.e., at lower flowering temperatures, and this effect was particularly pronounced in the upper part of the style. Genotype-dependent behaviour of pollinisers in terms of temperatures during the flowering did not manifest consistently. Besides sweet cherries
'Early Star' and 'Newstar', sour cherries 'Cigančica' and 'Feketićka' also induced a smaller number of pollen tubes during the cooler flowering season. In terms of pollen tube number, reproductive behaviour of sour cherries 'Čačanski Rubin' and 'Érdi Bötermö' was relatively independent of air temperatures; on the other hand, 'Majurka' induced a significantly smaller number of pollen tubes in the upper third of the style in the second year (their number in other parts of the style was more uniform per flowering season).

Table 1. Efficiency of pollen tube growth of different pollinisers in the pistils of sour cherry cultivar 'Feketićka'

\begin{tabular}{|c|c|c|c|c|c|c|}
\hline \multicolumn{2}{|c|}{$\begin{array}{l}\text { Variability } \\
\text { factor }\end{array}$} & $\begin{array}{l}\text { Upper third } \\
\text { of the style }\end{array}$ & $\begin{array}{c}\text { Base } \\
\text { of the style }\end{array}$ & Ovary & $\begin{array}{c}\text { Fertilisation } \\
\text { percentage }\end{array}$ & $\begin{array}{c}\text { Fruit } \\
\text { set }\end{array}$ \\
\hline \multicolumn{7}{|c|}{ Polliniser (factor A) } \\
\hline \multicolumn{2}{|l|}{ 'Cigančica' } & $20.07 \pm 5.21 \mathrm{~b}$ & $3.97 \pm 1.35 b$ & $1.81 \pm 0.37 \mathrm{~b}$ & $15.65 \pm 3.98 \mathrm{a}$ & $16.70 \pm 0.22 \mathrm{a}$ \\
\hline \multicolumn{2}{|l|}{ 'Čačanski Rubin' } & $14.56 \pm 0.71 \mathrm{~d}$ & $2.02 \pm 0.31 \mathrm{c}$ & $1.03 \pm 0.25 \mathrm{~cd}$ & $7.50 \pm 0.35 \mathrm{f}$ & $0.00 \pm 0.00 \mathrm{~g}$ \\
\hline \multicolumn{2}{|l|}{ 'Early Star' } & $23.07 \pm 4.59 \mathrm{~b}$ & $3.50 \pm 1.27 \mathrm{~b}$ & $1.03 \pm 0.41 \mathrm{~cd}$ & $10.45 \pm 0.16 \mathrm{e}$ & $4.55 \pm 0.23 \mathrm{~d}$ \\
\hline \multicolumn{2}{|l|}{ 'Erdi Bötermö' } & $7.36 \pm 0.47 \mathrm{e}$ & $0.50 \pm 0.00 \mathrm{~d}$ & $0.56 \pm 0.14 \mathrm{de}$ & $7.20 \pm 1.73 \mathrm{~g}$ & $1.50 \pm 0.31 \mathrm{f}$ \\
\hline \multicolumn{2}{|l|}{ 'Majurka' } & $8.12 \pm 1.14 \mathrm{e}^{-}$ & $0.45 \pm 0.08 \mathrm{~d}$ & $0.28 \pm 0.10 \mathrm{e}$ & $4.75 \pm 0.34 \mathrm{~h}$ & $3.75 \pm 0.33 \mathrm{e}$ \\
\hline \multicolumn{2}{|l|}{ 'Newstar' } & $39.53 \pm 3.14 \mathrm{a}$ & $9.93 \pm 0.64 \mathrm{a}$ & $2.57 \pm 0.10 \mathrm{a}$ & $10.75 \pm 2.12 \mathrm{~d}$ & $5.75 \pm 0.26 \mathrm{c}$ \\
\hline \multicolumn{2}{|l|}{ Self-pollination } & $15.63 \pm 2.85 \mathrm{~cd}$ & $1.50 \pm 0.30 \mathrm{c}$ & $1.47 \pm 0.22 \mathrm{bc}$ & $11.45 \pm 0.15 \mathrm{c}$ & $5.60 \pm 0.33 \mathrm{c}$ \\
\hline \multicolumn{2}{|l|}{ Open pollination } & $18.13 \pm 1.85 \mathrm{c}$ & $2.00 \pm 0.45 \mathrm{c}$ & $1.62 \pm 0.21 \mathrm{~b}$ & $15.20 \pm 3.79 \mathrm{~b}$ & $9.80 \pm 0.25 \mathrm{~b}$ \\
\hline \multicolumn{7}{|c|}{ Year (factor B) } \\
\hline \multicolumn{2}{|l|}{2016} & $23.30 \pm 2.58 \mathrm{a}$ & $3.92 \pm 0.73 \mathrm{a}$ & $1.53 \pm 0.20 \mathrm{a}$ & $14.05 \pm 1.32 \mathrm{a}$ & $4.95 \pm 1.45 \mathrm{a}$ \\
\hline \multicolumn{2}{|l|}{2017} & $13.32 \pm 1.70 \mathrm{~b}$ & $2.04 \pm 0.58 \mathrm{~b}$ & $1.06 \pm 0.15 \mathrm{~b}$ & $6.65 \pm 0.54 \mathrm{~b}$ & $4.30 \pm 1.41 \mathrm{~b}$ \\
\hline \multicolumn{7}{|c|}{$\mathrm{A} \times \mathrm{B}$} \\
\hline \multirow{2}{*}{ 'Cigančica' } & 2016 & $31.10 \pm 3.66 \mathrm{~b}$ & $6.84 \pm 0.84 c$ & $2.50 \pm 0.34 \mathrm{ab}$ & $28.40 \pm 0.13 \mathrm{a}$ & $17.00 \pm 0.18 \mathrm{a}$ \\
\hline & 2017 & $9.03 \pm 0.65 \mathrm{efg}$ & $1.08 \pm 0.30 \mathrm{f}$ & $1.11 \pm 0.29 \mathrm{de}$ & $6.20 \pm 0.12 \mathrm{i}$ & $16.45 \pm 0.13 \mathrm{a}$ \\
\hline \multirow{2}{*}{ 'Čačanski Rubin' } & 2016 & $14.59 \pm 1.19 \mathrm{~d}$ & $1.36 \pm 0.25 \mathrm{f}$ & $0.72 \pm 0.43 \mathrm{def}$ & $8.20 \pm 0.10 \mathrm{~g}$ & $0.00 \pm 0.00 \mathrm{a}$ \\
\hline & 2017 & $14.53 \pm 1.07 \mathrm{~d}$ & $2.67 \pm 0.00 \mathrm{~d}$ & $1.33 \pm 0.19 \mathrm{~cd}$ & $6.75 \pm 0.08 \mathrm{~h}$ & $0.00 \pm 0.00 \mathrm{a}$ \\
\hline \multirow{2}{*}{ 'Early Star' } & 2016 & $33.31 \pm 0.57 \mathrm{~b}$ & $6.32 \pm 0.17 \mathrm{c}$ & $1.83 \pm 0.42 \mathrm{bc}$ & $10.80 \pm 0.09 \mathrm{e}$ & $4.92 \pm 0.04 \mathrm{a}$ \\
\hline & 2017 & $12.83 \pm 0.33 \mathrm{de}$ & $0.67 \pm 0.17 \mathrm{f}$ & $0.22 \pm 0.11 \mathrm{f}$ & $10.10 \pm 0.03 \mathrm{f}$ & $4.10 \pm 0.19 \mathrm{a}$ \\
\hline \multirow{2}{*}{ ‘Érdi Bötermö’ } & 2016 & $7.33 \pm 0.98 \mathrm{~g}$ & $0.50 \pm 0.00 \mathrm{f}$ & $0.45 \pm 0.22 \mathrm{ef}$ & $11.10 \pm 0.03 \mathrm{e}$ & $1.12 \pm 0.51 \mathrm{a}$ \\
\hline & 2017 & $7.38 \pm 0.35 \mathrm{~g}$ & $0.50 \pm 0.00 \mathrm{f}$ & $0.67 \pm 0.19 \mathrm{def}$ & $4.10 \pm 0.08 \mathrm{k}$ & $0.85 \pm 0.04 \mathrm{a}$ \\
\hline \multirow{2}{*}{ 'Majurka' } & 2016 & $10.66 \pm 0.03 \mathrm{def}$ & $0.56 \pm 0.11 \mathrm{f}$ & $0.22 \pm 0.11 \mathrm{f}$ & $5.30 \pm 0.13 \mathrm{j}$ & $4.41 \pm 0.19 \mathrm{a}$ \\
\hline & 2017 & $5.59 \pm 0.12 \mathrm{~g}$ & $0.33 \pm 0.08 \mathrm{f}$ & $0.33 \pm 0.19 \mathrm{f}$ & $4.20 \pm 0.14 \mathrm{k}$ & $3.16 \pm 0.43 \mathrm{a}$ \\
\hline \multirow{2}{*}{ 'Newstar' } & 2016 & $45.75 \pm 3.19 \mathrm{a}$ & $10.81 \pm 0.57 \mathrm{a}$ & $2.68 \pm 0.09 a$ & $16.35 \pm 0.16 c$ & $6.22 \pm 0.08 \mathrm{a}$ \\
\hline & 2017 & $33.31 \pm 0.57 \mathrm{~b}$ & $9.04 \pm 0.96 \mathrm{~b}$ & $2.47 \pm 0.17 \mathrm{ab}$ & $6.15 \pm 0.11 \mathrm{i}$ & $5.11 \pm 0.30 \mathrm{a}$ \\
\hline \multirow{2}{*}{ Self-pollination } & 2016 & $21.57 \pm 2.32 \mathrm{c}$ & $2.00 \pm 0.35 \mathrm{de}$ & $1.86 \pm 0.18 b c$ & $11.80 \pm 0.05 \mathrm{~d}$ & $6.25 \pm 0.12 \mathrm{a}$ \\
\hline & 2017 & $9.70 \pm 0.16$ efg & $1.00 \pm 0.29 \mathrm{f}$ & $1.07 \pm 0.22 \mathrm{de}$ & $11.10 \pm 0.03 \mathrm{e}$ & $5.00 \pm 0.04 \mathrm{a}$ \\
\hline \multirow{2}{*}{ Open pollination } & 2016 & $22.08 \pm 1.05 \mathrm{c}$ & $3.00 \pm 0.12 \mathrm{~d}$ & $1.95 \pm 0.31 \mathrm{bc}$ & $20.00 \pm 0.06 \mathrm{a}$ & $10.48 \pm 0.16 \mathrm{a}$ \\
\hline & 2017 & $14.17 \pm 0.66 \mathrm{~d}$ & $1.00 \pm 0.00 \mathrm{f}$ & $1.28 \pm 0.05 \mathrm{~cd}$ & $6.23 \pm 0.05 \mathrm{i}$ & $9.11 \pm 0.26 \mathrm{a}$ \\
\hline \multicolumn{7}{|c|}{ ANOVA } \\
\hline \multicolumn{2}{|l|}{$\bar{A}$} & ** & $* *$ & ** & ** & ** \\
\hline \multicolumn{2}{|l|}{ B } & $* *$ & ** & $* *$ & $* *$ & ** \\
\hline \multicolumn{2}{|l|}{$\mathrm{A} \times \mathrm{B}$} & $* *$ & $* *$ & $* *$ & ** & ns \\
\hline
\end{tabular}

Note. ${ }^{* *}$ - significant at $P \leq 0.05, \mathrm{~ns}$ - not significant according to Duncan's multiple range test; mean values followed by the different lower-case letters in the column represent significant differences.

In both experimental years and in all combinations, pollen tubes were observed in the ovary on the $3^{\text {rd }}$ day after pollination, except with sour cherry 'Majurka' as polliniser. On this fixation term, pollen tubes of sour cherry 'Cigančica' and sweet cherry 'Early Star' did not reach the ovary in the second year of the experiment (Figure 4). On the $6^{\text {th }}$ day after pollination, the pistils generally had the longest pollen tubes in obturator zone, micropyle or nucellus, while on the $10^{\text {th }}$ day pollen tubes were found in the nucellus in all pollination modes and in both experimental years.

Lower flowering temperatures caused generally poorer efficiency, but cultivar specificities were noticed: some pollinisers (sour cherry 'Cigančica') had slower growth rates by fixation terms at these temperatures. A similar effect was also observed in the open pollination mode. In some pollinisers ('Early Star' and 'Majurka'), the effect was observed in the first term of fixation, whereas in the second term growth rates were equalized by flowering seasons. Concerning these traits, sour cherries 'Érdi Bötermö' and 'Feketićka' behaved similarly per flowering seasons in both fixation terms.

Fertilisation percentages were generally better in the first experimental year, but the trend was unequally expressed. It was more clearly manifested when pollinated with pollen of 'Cigančica', 'Érdi Bötermö' and 'Newstar' as pollinisers as well as in open pollination variant, whereas the differences were expressed in smaller degree for the other pollinisers. The lowest values of fertilisation percentage were found in 2017 for 'Érdi Bötermö' and 'Majurka' as pollinisers: $4.10 \%$ and $4.20 \%$, respectively (Table 1 ). Considering all the pollen tube dynamics parameters, the results for sour cherries 'Cigančica' and 'Majurka' as well as for sweet cherry 'Early Star' are in accordance with Hedhly et al. (2007), who stated that higher temperatures increase the rate of pollen tube growth but only in the first few days after pollination. For sour cherries 'Érdi Bötermö' and 


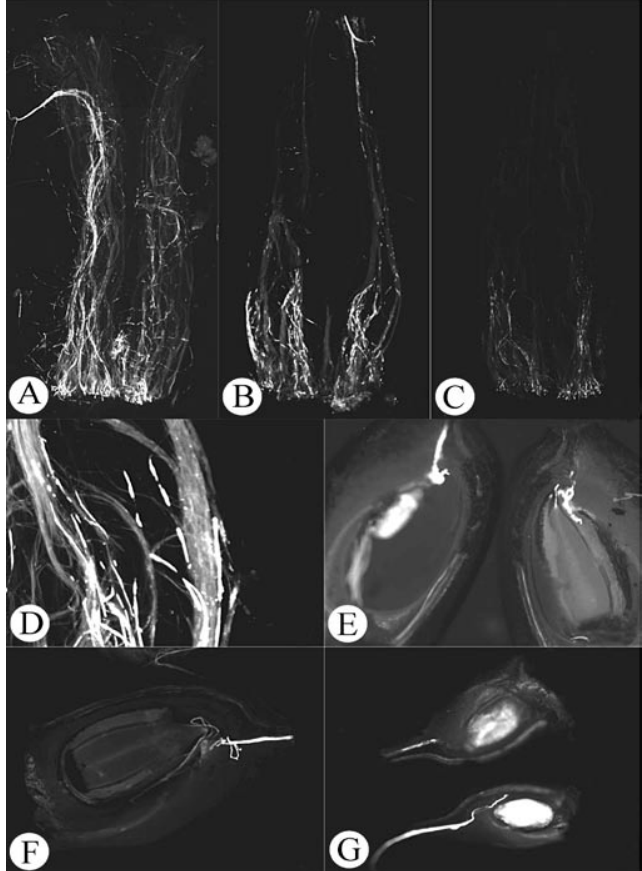

'Feketićka' $\times$ 'Cigančica', day 3 after pollination (A); 'Feketićka', open pollination mode, day 6 (B); 'Feketićka' $\times$ 'Čačanski Rubin', day 6 (C); incompatible pollen tubes in the upper third of the style, 'Feketićka' SP, day 3 (D); penetration into the nucellus, 'Feketićka' × 'Newstar', day $6(\mathrm{E})$; unusual pollen tube growth in the ovary - a bundle of pollen tubes and reverse growth in the obturator zone $(\mathrm{F})$; the strong fluorescence of the entire primary ovule $(\mathrm{G})$

Figure 3. Growth of pollen tubes in the pistils of sour cherry cultivar 'Feketićka
'Feketićka' and for sweet cherry 'Newstar' this influence is more visible in the later days of flowering. Considering that temperatures during the flowering season in 2016 were more typical of the area, whereas 2017 was cooler than usual, it can be concluded that autochthonous sour cherry cultivars 'Cigančica', 'Feketićka' and 'Majurka' as pollinisers are better adapted to conditions during the flowering. This is in line with Hedhly et al. (2004), who stated that the behaviour of autochthonous genotypes in terms of reproductive characteristics reflects their geographic origin.

On the contrary, sour cherries 'Čačanski Rubin' and 'Érdi Bötermö' exhibited reproductive behaviour, which was not dependent on temperature in that extent. Although 'Cačanski Rubin' generally behaved like a poor polliniser, in some parameters of pollen tube kinetics it was better in colder flowering conditions. Similar results were reported for sour cherry 'Latvijas Zemais', which showed better results as polliniser in the years with lower temperatures (Feldmane et al., 2017). Sweet cherries behaved similarly, whereby 'Newstar' showed better performance in terms of pollen tube number than all the pollinisers. The parameters of dynamics also had high values but not as high as when pollinated with pollen of 'Cigančica' sour cherry.

The results indicate that the cultivar specificities at different temperatures were fully manifested reflecting the wide range in terms of their male behaviour. Thus, in sweet cherry 'Early Star', higher temperatures induced a higher number of pollen tubes but did not increase their kinetics, whereas in sour cherry 'Érdi Bötermö', they did not affect the increase in pollen tube number but affected their kinetics.

The highest and the lowest values of fruit set were recorded for sour cherries 'Cigančica' and 'Čačanski Rubin' as pollinisers: $16.70 \%$ and $0.00 \%$, respectively

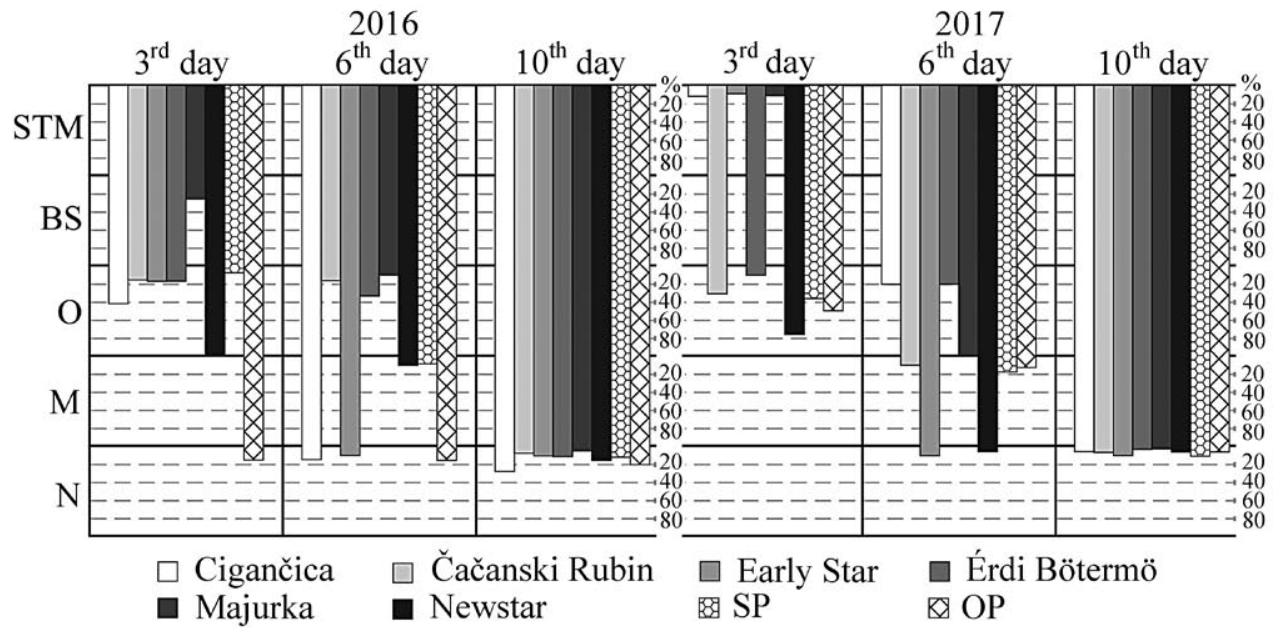

STM - middle third of the style, BS - base of the style, $\mathrm{O}$ - obturator zone, $\mathrm{M}$ - micropyle, $\mathrm{N}$ - nucellus of the ovule; $\%$ - the rate of pistils with the longest pollen tube in their certain parts; $\mathrm{SP}$ - self polination, $\mathrm{OP}$ - open polination

Figure 4. Dynamics of pollen tube growth through the certain pistil parts of sour cherry cultivar 'Feketićka'

(Table 2). Although 2016 season was more conducive to the reproductive process than 2017 one, it was also not an ideal season. An increase of temperature above $10^{\circ} \mathrm{C}$ (three days after pollination and later) accelerated the pollen tube growth and shortened the time required to reach the base of the style and at the same time did not negatively affect the fruit set (Radunić et al., 2017). In the study of Feldmane et al. (2017), a negative effect of increasing average daily air temperature during flowering on fruit set was pronounced for several sour cherry cultivars. Therefore, the fruit set in this experiment was not much better in the year that had more favourable conditions during the flowering. Incidence of seasons with high temperatures during flowering reduces the fertility of cultivated plants due to sensitivity of different phases of the reproductive process to higher temperatures resulting in gradual changes in the distribution of cultivars (Hedhly, 2011).

Pollen performance and impact of a pollinated cultivar. The influence of 'Feketićka' as pollinated cultivar was primarily manifested in the style through gametophytic-incompatibility reaction that eliminated 
support to gametophytes with a similar genetic constitution. In all the variants incompatible pollen tubes were observed in the upper and in the middle third of the style (Figure 3D).

Results implied that 'Feketićka' is not selfincompatible: although self-pollen successfully reached the ovule in some pistils, it is not self-compatible either. According to the classification of Schuster et al. (2017), partially self-compatible sour cherries after selfing set fruits in the range from $1 \%$ to $14 \%$, so 'Feketićka' belongs to that category - on average, less than $6.00 \%$ of fruit set after selfing (Table 1). Pollen tube growth parameters of sour cherry cultivars 'Cačanski Rubin' and 'Érdi Bötermö' had lower values than self-pollen as well as than pollen of sweet cherries. This could not confirm the findings obtained by Cachi et al. (2014), according to which self-pollen grows slower than foreign pollen.

In the ovary, fluorescence of the primary ovules was observed in all pollination modes as well as in both years. The phenomenon had developmental stages from mild fluorescence of halase to the strong fluorescence of the entire ovule, which was often accompanied by the fluorescence of the surrounding tissue: obturator, funiculus and ovary tissue (Figure $3 \mathrm{G}$ ). The penetration of the pollen tube in these ovules was noted just in few cases. The percentage of ovaries without fluorescence signs was higher on the $3^{\text {rd }}$ than on the $6^{\text {th }}$ day after full flowering began in all the pollination modes (Table 2). Additionally, ovule longevity was better in open pollination mode than in cross- and self-pollination ones and in 2017 than in the 2016 season. The seasonal impacts were manifested with unequal strength resulting in the statistical significance of interaction of the pollination mode and year. The dependence on genotype and influence of higher temperatures on ovule senescence acceleration in Prunus species was previously reported (Guerra et al., 2011; Radičević et al., 2018; Đorđević et al., 2019). The lower percentage of primary ovules with signs of fluorescence in open pollination mode can be interpreted as a positive effect of the emasculation absence, as shown in sweet cherries (Hedhly et al., 2009).

It is interesting that, regarding the flowering temperatures, 'Feketićka' manifested opposite male/ female behaviour, preferring higher temperatures as a polliniser and lower temperatures as a pollinated cultivar.

Table 2. The percentage of ovaries with non-fluorescent primary ovules in cross-, self- and open-pollinated flowers of sour cherry cultivar 'Feketićka'

\begin{tabular}{|c|c|c|}
\hline $\begin{array}{c}\text { Variability } \\
\text { factor }\end{array}$ & $\begin{array}{l}3^{\text {rd }} \text { day after } \\
\text { full flowering } \\
\text { beginning }\end{array}$ & $\begin{array}{c}6^{\text {th }} \text { day after } \\
\text { full flowering } \\
\text { beginning }\end{array}$ \\
\hline \multicolumn{3}{|c|}{ Pollination mode (factor A) } \\
\hline Cross-pollination & $69.39 \pm 3.14 b$ & $51.81 \pm 1.79 \mathrm{~b}$ \\
\hline Self-pollination & $66.34 \pm 0.09 \mathrm{c}$ & $42.73 \pm 0.66 \mathrm{c}$ \\
\hline Open pollination & $87.50 \pm 6.69 \mathrm{a}$ & $71.28 \pm 0.54 \mathrm{a}$ \\
\hline \multicolumn{3}{|c|}{ Year (factor B) } \\
\hline 2016 & $66.45 \pm 1.49 \mathrm{~b}$ & $52.72 \pm 3.04 \mathrm{~b}$ \\
\hline 2017 & $82.37 \pm 5.30 \mathrm{a}$ & $57.83 \pm 2.04 \mathrm{a}$ \\
\hline \multicolumn{3}{|c|}{$A \times B$} \\
\hline \multirow{2}{*}{ Cross-pollination } & $58.35 \pm 0.08 \mathrm{f}$ & $44.82 \pm 0.02 \mathrm{~d}$ \\
\hline & $80.43 \pm 0.07 \mathrm{~b}$ & $58.80 \pm 0.02 \mathrm{c}$ \\
\hline \multirow{2}{*}{ Self-pollination } & $66.00 \pm 0.00 \mathrm{e}$ & $40.00 \pm 0.18 \mathrm{e}$ \\
\hline & $66.67 \pm 0.14 \mathrm{~d}$ & $45.45 \pm 0.10 \mathrm{~d}$ \\
\hline \multirow{2}{*}{ Open pollination } & $100.00 \pm 0.00 \mathrm{a}$ & $69.23 \pm 0.15 b$ \\
\hline & $75.00 \pm 0.09 \mathrm{c}$ & $73.33 \pm 0.07 \mathrm{a}$ \\
\hline \multicolumn{3}{|c|}{ ANOVA } \\
\hline A & $* *$ & $* *$ \\
\hline B & $* *$ & $* *$ \\
\hline $\mathrm{A} \times \mathrm{B}$ & $* *$ & $* *$ \\
\hline
\end{tabular}

Note. ${ }^{* *}$-indicate the level of significance at $P \leq 0.05$, according to Duncan's multiple range test; mean values followed by the different lower-case letters in the column represent significant differences.
Its reproductive behaviour is related to good adaptability to the agro-ecological conditions of the Pannonian Basin, where 'Feketićka' can achieve remarkable results in favourable seasons and at least satisfactory results in seasons with less favourable conditions. However, its cultivation in the sub-mountainous and mountainous regions of other parts of Serbia generally did not give satisfactory results in terms of fertility potential, particularly in comparison with the cultivar 'Heimanns Konserven Weichsel' or domestic cultivars having it in pedigree ('Sumadinka' and 'Sofija'). In addition to possible weaker adaptability, the reason also may be the choice of inadequate polliniser(s). Anyway, reproductive behaviour of sour cherry cultivars should be considered in the context of their adaptation to different environmental conditions, particularly from the viewpoint of increasing incidence of seasons with lower/higher temperatures during the flowering and favouring those that are better adapted.

Correlation between reproductive parameters and final fertilisation outcome. The correlation between pollen germination in vitro and pollen tube number in the upper third of the style was significant positive and medium strong $(r=0.64)$ (Table 3$)$. Similar values were obtained for coefficients between the pollen germination in vitro and the pollen tube number in the base of the style and in the ovary as well. Pollen germination in vitro did not affect fertilisation percentage but affected fruit set (weak positive correlation; $r=0.44$ ). The results confirmed the previous findings for sweet cherry, where pollen tube growth in vivo correlated with pollen germination in vitro (Radičević et al., 2016).

Table 3. Pearson's coefficients of linear correlation between the reproductive parameters

\begin{tabular}{ccccccc}
\hline Parameter & PG & STU & BS & OVR & FP & FS \\
\hline PG & $/$ & & & & & \\
STU & $0.64^{*}$ & $/$ & & & & \\
BS & $0.66^{*}$ & $0.94^{*}$ & $/$ & & & \\
OVR & $0.53^{*}$ & $0.83^{*}$ & $0.84^{*}$ & $/$ & & \\
FP & -0.10 & $0.45^{*}$ & 0.28 & $0.44^{*}$ & $/$ & \\
FS & $0.44^{*}$ & $0.35^{*}$ & 0.29 & $0.37^{*}$ & $0.45^{*}$ & $/$ \\
\hline
\end{tabular}

PG - pollen germination in vitro, STU - pollen tube number in the upper third of the style, BS - pollen tube number in the base of the style, OVR - pollen tube number in the ovary, $\mathrm{FP}$ - fertilisation percentage, $\mathrm{FS}$ - fruit set; * - significant at $P \leq 0.05$

Due to the fact that the experimental possibilities for monitoring the competitiveness of different pollinisers in the same pistil are limited, little information is available concerning the relationship between the pollen tube number and growth rate. Weak to moderate correlations were observed between pollen tube number in the upper third of the pistils and in the ovary and fertilisation percentage (Table 3). The pollen tube number in the base of the style did not affect fertilisation percentage and fruit set. On the other hand, pollen tube number in the ovary significantly affected (weak correlation) these parameters $(r=0.44$ and $r=0.43$, respectively); between the two parameters a weak correlation $(r=0.45)$ was also determined. This fact indicates that a higher pollen tube number gives preconditions for better efficiency in terms of penetration into the nucellus, i.e., the favouring of certain cultivars as pollinisers primarily achieved through the higher number of their pollen tubes, which gives a better chance for successful fertilisation.

The correlations obtained for parameters related to ovule longevity showed a medium-strong to a strong positive correlation between the percentage of vital ovules on the $6^{\text {th }}$ day after pollination and fertilisation 
percentage (emasculated flowers) $(r=0.69)$. For nonemasculated flowers (open pollination mode), a strong positive correlation between the percentages of vital ovules on fixation dates $(r=0.96)$ and medium-strong correlation between fertilisation percentage and fruit set $(r=0.59)$ were obtained (Table 4).

Table 4. Pearson's coefficients of linear correlation between the reproductive parameters

\begin{tabular}{ccccc}
\hline Parameter & $\mathrm{O}^{\text {rd }}$ & $\mathrm{O}^{\text {th }}$ & FP & FS \\
\hline \multicolumn{4}{c}{ Emasculated flowers (self- and cross-pollination) } \\
\hline O3 $^{\text {rd }}$ & $/$ & & \\
O6 $^{\text {th }}$ & 0.67 & $/$ & \\
FP & -0.23 & $-0.69 *$ & $/$ \\
FS & -0.21 & 0.04 & 0.45 & $/$ \\
\hline \multicolumn{4}{c}{ Non-emasculated flowers (open pollination) } \\
\hline O3 $^{\text {rd }}$ & $/$ & $/$ & \\
O6 $^{\text {th }}$ & $0.96^{*}$ & -0.37 & $/$ \\
FP & -0.13 & $-0.59 *$ & $/$ \\
FS & 0.19 & -0.05 & $0.59 *$
\end{tabular}

$\mathrm{O} 3^{\text {rd }}$ - a percentage of ovaries without fluorescence signs, $3^{\text {rd }}$ day after anthesis, $\mathrm{O}^{\text {th }}$ - a percentage of ovaries without fluorescence signs, $6^{\text {th }}$ day after anthesis; FP - fertilisation percentage, FS - fruit set; * - significant at $P \leq 0.05$

In all pollination modes, the ovaries with unusual pollen tube growth were observed as being particularly pronounced in the obturator area before further penetration of pollen tubes towards the micropyle and nucellus - a bundle of pollen tubes as well as recurrent growth in obturator zone (Figure 3E). Ovary tissues provide various types of signals that orient and guide pollen tubes (Palanivelu, Tsukamoto, 2012), and loss of this orientation has been described as chaotic (unusual) growth. The level of unusual pollen tube growth occurrence was expressed in a significantly lower extent than in sweet cherry in similar environmental conditions (Radičević et al., 2018). The final outcome manifested as fruit set was not obtained from just pollen-pistil interaction but from the overlapping effect of several factors: polliniser genotype, behaviour of pollinisers at different temperatures, the influence of pollinated cultivar on pollen performance and of temperature on male-female relations. Results of our experiment are in line with those of Radunić et al. (2017), according to which the pistil may modulate the result of pollen donor performance and fertilisation success is highly dependent on the interaction between the pollen tube and pistil tissues.

From the agronomic point of view, when fruit set consistently falls below acceptable levels, growers may increase it by raising the availability of compatible pollen. Even though 'Feketićka' did not behave as selfincompatible, it should not be grown as a monoculture. The best pollen performance in vivo was shown by sour cherry 'Cigančica', that was also the most successful at achieving fertilisation in pistils of 'Újfehértói Fürtös' (Sebolt, Iezzoni, 2009). Pollinisers should be carefully chosen, although the ovule longevity of 'Feketićka' was not too short. It is possible that pollen tubes do not have enough time to successfully complete fertilisation in years with higher flowering temperatures, because the degree of ovule senescence drastically accelerates at these temperatures.

\section{Conclusions}

1.Autochthonous sour cherry cultivar 'Feketićka' spread in Vojvodina Province of the Republic of Serbia is a partially self-fertile cultivar that forms less than $6 \%$ of fruits with its own pollen, so it should not be grown as a monoculture.
2. Among the investigated pollinisers, the best performance was shown by the autochthonous cultivar 'Cigančica' ('Cigány Meggy'), whereas 'Čačanski Rubin' and 'Érdi Bötermö' are not surely recommended as pollinisers for 'Feketićka'.

3. Regarding the air temperatures before/ during the flowering, 'Feketićka' showed the opposite requirements in reproductive male/female behaviour preferring somewhat higher temperatures as polliniser, i.e., lower temperatures as pollinated cultivar.

4. Future research should be aimed at finding suitable pollinisers primarily among commercial sour cherry cultivars. As for sweet cherries as pollinisers for 'Feketićka', the obtained results are encouraging enough to continue finding those with adequate flowering time, good flowering abundance and pollen quality.

\section{Acknowledgements}

This research was conducted under the support of the Ministry of Education, Science and Technological Development of the Republic of Serbia, contracts No. 451$03-9 / 2021-14 / 200215$ and 451-03-9/2021-14/200117.

Received 06112020 Accepted 03052021

\section{References}

Arbeloa A., Herrero M. 1985. Valoración de la translocación al óvulo de la esterilidad femenina en melocotonero. Anales de la Estación Experimental de Aula Dei, 17 (3-4): 214 220 (in Spanish). http://hdl.handle.net/10261/13627

Cachi A. M., Hedhly A., Hormaza J. I., Wünsch A. 2014. Pollen tube growth in the self-compatible sweet cherry genotype, 'Cristobalina', is slowed down after self-pollination. Annals of Applied Biologv. 164 (1): 73-84. https://doi.org/10.1111/aab.12079

Đorđević M., Cerović R., Radičević S., Nikolić D., Milošević N., Glišić I., Marić S., Lukić M. 2019. Pollen tube growth and embryo sac development in 'Pozna Plava' plum cultivar related to fruit set. Erwerbs-Obstbau. 61: 313-322. https://doi.org/10.1007/s10341-019-00431-7

Feldmane D., Ruisa S., Pole V., Butac M., Militaru M. 2017. Fruit set of several sour cherry cultivars in Latvia influenced by weather conditions before and during flowering. Proceedings of the Latvian Academv of Sciences. Section B, 71 (3): 178-183. https://doi.org/10.1515/prolas-2017-0030

Fotirić Akšić M., Cerović R., Ercişli S., Jensen M. 2016. Microsporogenesis and meiotic abnormalities in different 'Oblačinska' sour cherry (Prunus cerasus L.) clones. Flora, 219: 25-34. https://doi.org/10.1016/j.flora.2015.12.009

Fotirić Akšić M., Cerović R., Rakonjac V., Bakić I., Colić S., Meland M. 2017. Vitality and in vitro pollen germination of different 'Oblacinska' sour cherry clones. Genetika, 49 (3): 791-800. https://doi.org/10.2298/GENSR1703791A

Guerra E. M., Wünsch A., López-Corrales M., Rodrigo J. 2011. Lack of fruit set caused by ovule degeneration in Japanese plum. Journal of the American Society for Horticultural Science, 136 (6): 375-381 https://doi.org/10.21273/JASHS.136.6.375

Hedhly A. 2011. Sensitivity of flowering plant gametophytes to temperature fluctuations. Environmental and Experimental Botany, 74: 9-16. https://doi.org/10.1016/j.envexpbot.2011.03.016

Hedhly A., Hormaza J. I., Herrero M. 2004. Effect of temperature on pollen tube kinetics and dynamics in sweet cherry, Prunus avium (Rosaceae). American Journal of Botany, 91 (4): 558-564. httns://www.istor.org/stable/4123684. https://doi.org/10.3732/ajb.91.4.558

Hedhly A., Hormaza J. I., Herrero M. 2007. Warm temperatures at bloom reduce fruit set in sweet cherry. Journal of Applied Biology and Food Quality, 81 (2): 158-164. http://hdl. handle.net/10261/4386 
Hedhly A., Hormaza J. I., Herrero M. 2009. Flower emasculation accelerates ovule degeneration and reduces fruit set in sweet cherry. Scientia Horticulturae, 119 (4): 455-457. https://doi.org/10.1016/j.scienta.2008.08.020

Iezzoni A. F., Wünsch A., Höfer M., Giovannini D., Jensen M., Quero-Garcia J., Campoy J. A., Vokurka A., Barreneche T. 2017. Biodiversity, germplasm resources and breeding methods. Quero-Garcia J. et al. (eds). Cherries: Botany, Production and Uses. CABI Publishing. n. 36-59. https://doi.org/10.1079/9781780648378.0036

Kho Y. O., Baër J. 1971. Fluorescence microscopy in botanical research. Zeiss Information, 76: 54-57.

Meier U. 2018. Growth stages of mono- and dicotyledonous plants: BBCH Monogranh, $204 \mathrm{n}$. https://doi.org/10.5073/20180906-074619

Ognjanov V., Miodragović M., Barać G., Prvulović D., Ljubojević M., Dulić J., Dorić D. 2016. 'Prima' sour cherry. HortScience. 51 (2): 202-205. https://doi.org/10.21273/HORTSCI.51.2.202

Pal M., Mitre V., Tripon A., Macavei L., Lazar M. 2015. Pollen viability and germination capacity of some new sweet cherry cultivars. Bulletin UJASVM Clui-Nanoca. Horticulture. 72 (1): 223-224. https://doi.org/10.15835/buasvmen-hort:10645

Palanivelu R., Tsukamoto T. 2012. Pathfinding in angiosperm reproduction: pollen tube guidance by pistils ensures successful double fertilization. WIREs: Develonmental Biology, 1 (1): 96-113. https://doi.org/10.1002/wdev.6

Pimienta E., Polito V. S. 1982. Ovule abortion in 'Nonpareil' almond (Prunus dulcis (Mill) D. A. Webb). American Journal of Botany, 69 (6): 913-920. https://doi.org/10.2307/2442888

Preil W. 1970. Observing of pollen tube in pistil and ovarian tissue by means of fluorescence microscopy. Zeiss Information, 75: 24-25.

Radičević S., Cerović R., Lukić M., Paunović S. A., Jevremović D., Milenković S., Mitrović M. 2012. Selection of autochthonous sour cherry (Prunus cerasus L.) genotypes in Feketić region. Genetika, 44 (2): 285-297. https://doi.org/10.2298/GENSR1202285R

Radičević S., Nikolić D., Cerović R., Đorđević M. 2013. In vitro pollen germination and pollen grain morphology in some sweet cherry (Prunus avium L.) cultivars. Romanian Biotechnological Letters, 18 (3): 8341-8349.
Radičević S., Cerović R., Nikolić D., Đorđević M. 2016. The effect of genotype and temperature on pollen tube growth and fertilization in sweet cherry (Prunus avium L.). Euphytica, 209: 121-136. https://doi.org/10.1007/s10681-016-1645-y

Radičević S., Cerović R., Đorđević M. 2018. Ovule senescence and unusual pollen tube growth in the ovary of sweet cherry as affected by pistilar genotype and temperature. Spanish Journal of Agricultural Research. 16 (4): e0704. https://doi.org/10.5424/sjar/2018164-13094

Radunić M., Jazbec A., Ercisli S., Cmelik Z., Goreta Ban S. 2017. Pollen-pistil interaction influence on the fruit set of sweet cherry. Scientia Horticulturae. 224: 358-366. https://doi.org/10.1016/j.scienta.2017.06.010

Schuster M., Apostol J., Iezzoni A. F., Jensen M., Milatovic'D. 2017. Sour cherry varieties and improvement. QueroGarcía J. et al. (eds.). Cherries: Botany, Production and Uses. CABI Publishing. p. 95-116. https://doi.org/10.1079/9781780648378.0095

Sebolt A. M., Iezzoni A. F. 2009. Utilization of the S-locus as a genetic marker in cherry to differentiate among different pollen donors. HortScience, 44 (6): 1542-1546. https://doi.org/10.21273/HORTSCI.44.6.1542

Stösser R., Anvari S. F.1982. On the senescence of ovules in cherries. Scientia Horticulturae. 16 (1): 29-38. https://doi.org/10.1016/0304-4238(82)90021-8

Szügyi S., Apostol J., Rozsnyay Zs., Bujdosó G., Sárdi É. 2016. Examination of disease resistant sour cherry genotypes bred in Hungary. Acta Horticulturae. 1139 (3): 13-18. https://doi.org/10.17660/ActaHortic.2016.1139.3

Tsukamoto T., Hauck N. R., Tao R., Jiang N., Iezzoni A. F. 2010. Molecular and genetic analyses of four nonfunctional $\mathrm{S}$ haplotype variants derived from a common ancestral S haplotype identified in sour cherry (Prunus cerasus L.). Genetics. 184 (2): 411-427. https://doi.org/10.1534/genetics.109.109728

Wenden B., Mariadassou M. 2017. Sweet cherry phenology in the context of climate change: a systems biology approach. Acta Horticulturae. 1162: 31-37. https://doi.org/10.17660/ActaHortic.2017.1162.6

\title{
Genotipo ir temperatūros sąveikos įtaka žiedadulkių veiksmingumui veislès 'Feketićka' autochtoninès vyšnios piestelèse
}

\author{
S. Radičević ${ }^{1}$, V. Ognjanov², S. Marić1, G. Barać ${ }^{2}$ \\ ${ }^{1}$ Vaisių tyrimų institutas, Serbija \\ ${ }^{2}$ Novi Sado universiteto Žemès ūkio fakultetas, Serbija
}

\begin{abstract}
Santrauka
Tirtas autochtoninės vyšnios (Prunus cerasus L.) veislès 'Feketićka' žiedadulkių veiksmingumas in vivo piestelèse, esant skirtingiems apdulkinimo būdams. Eksperimento metu tirtos savidulkès ir kryžmadulkès vyšnios veislès 'Cigančica', ‘Čačanski Rubin', 'Érdi Bötermö' bei 'Majurka', trešnès veislès 'Early Star' bei 'Newstar' ir laisvo apsidulkinimo variantas.

Eksperimento rezultatai analizuoti atsižvelgiant ị Serbijos Respublikos Vojvodinos provincijos, kurioje veislès 'Feketićka' vyšnios plačiai auginamos, agroekologines sąlygas. Tirtų veiksnių j̨taka dulkiadaigių augimo efektyvumui pasireiškè kaip žiedadulkių genotipo, jo poreikio temperatūrai žydẻjimo metu, moteriškojo genotipo ịtakos ir vyriškojo bei moteriškojo santykio atsako ị oro temperatūrą bendras poveikis. Veislè 'Feketićka', kuri po savaiminio apsidulkinimo užmezga mažiau nei $6 \%$ vaisių, gali būti priskiriama iš dalies savidulkių veisliu grupei. Iš tirtų veislès 'Feketićka' apdulkintojų efektyviausia buvo veislè 'Cigančica', o 'Čačanski Rubin' ir 'Érdi Bötermö’ nerekomenduotinos. Priklausomai nuo oro temperatūros žydejiimo metu, veislè 'Feketićka' kaip apdulkintojas pirmenybę teikẻ aukštesnei, o kaip apdulkinama veislè - žemesnei temperatūrai.
\end{abstract}

Reikšminiai žodžiai: autochtoninė veislè, žydejjimo temperatūra, vaisių užsimezgimas, sẻklapradžio gyvybingumas, žiedadulkių vamzdelių augimas, Prunus cerasus. 